\title{
Influence of Isolation Method on Recovery of Pythium Species from Forest Nursery Soils in Oregon and Washington
}

Jerry E. Weiland, United States Department of Agriculture - Agricultural Research Service, Horticultural Crops Research Laboratory, and Oregon State University, Department of Botany and Plant Pathology, Corvallis, OR 97331

\begin{abstract}
Weiland, J. E. 2011. Influence of isolation method on recovery of Pythium species from forest nursery soils in Oregon and Washington. Plant Dis. 95:547-553.

Pythium species are common damping-off pathogens that can cause stunting, chlorosis, and death of conifer seedlings in the Pacific Northwest (PNW) region of the United States. Despite the prevalence and importance of these pathogens in forest nurseries, relatively little is known about the identity of Pythium species associated with forest nursery soils in Washington and Oregon. A limited number of studies have reported $P$. aphanidermatum, $P$. irregulare, $P$. mamillatum, and $P$. ultimum as the predominant species in the PNW, but most studies of this genus in forest nurseries have not reported Pythium species identity. In an attempt to identify Pythium species associated with forest nursery soils, field surveys were conducted at three forest nurseries (two in Oregon and one in Washington) in 2008 using three isolation

methods. Pythium species were isolated by plating soil onto a semiselective medium or by baiting soil with rhododendron leaf disks and Douglas-fir needle segments. One hundred isolates were randomly selected from each isolation method at each nursery (900 isolates total) and identified on the basis of the internal transcribed spacer (ITS) sequence. Nineteen Pythium species were identified during the survey. Species richness and abundance were strongly influenced by both nursery and isolation method. Of the 300 isolates obtained from each nursery, $P$. irregulare was the most commonly isolated species from nursery A in Washington (65\% incidence). P. 'vipa' and P. dissotocum were the most commonly isolated species from nurseries $\mathrm{B}$ and $\mathrm{C}$ in Oregon, respectively (53 and 47\% incidence, respectively).
\end{abstract}

Forest nurseries of the Pacific Northwest (PNW) region of the United States, defined here as the states of Idaho, Oregon, and Washington, produce almost 200 million conifer seedlings each year (6). Approximately 75 million of the seedlings sold are 2year-old transplants of barefoot Douglas-fir (Pseudotsuga menziesii) (industry sales data, unpublished). Seedlings are used to reforest harvested land (13) and to replace stands destroyed by diseases, insects, or fire. Seedlings are also sold as stock for the Christmas tree and ornamental nursery industries (industry sales data, unpublished).

Pythium species are considered to be one of the most important soilborne pathogens limiting conifer seedling production in the PNW $(6,40)$. These pathogens are common soil inhabitants and are frequently isolated from forest nursery soils $(13,18)$. Pythium species cause damping-off and root rot of seeds and seedlings, particularly when soil moisture is abundant. Infection typically occurs early in the growing season when soils are still moist and cool, and seedling tissues are young. Symptoms associated with damping-off and root rot include failure of seed to germinate (preemergent damping-off), stunting, chlorosis, wilting, and up to $100 \%$ seedling mortality $(14,26,40)$.

At least 20 Pythium species have been associated with conifer seedlings worldwide $(2,13,14,16-19,25,26,33,41,43)$, with $P$. aphanidermatum, $P$. irregulare, $P$. mamillatum, and $P$. ultimum cited as the most prevalent species causing damping-off in the PNW $(13,18,19)$. Pythium species have been traditionally identified on the basis of microscopic characteristics and colony morphology $(13,25)$. However, identification based on these features is difficult and time intensive due to variation in morphological traits $(8,41)$,

Corresponding author: Jerry Weiland, E-mail: Jerry.Weiland@ars.usda.gov Accepted for publication 20 December 2010.

doi:10.1094/PDIS-04-10-0242

This article is in the public domain and not copyrightable. It may be freely reprinted with customary crediting of the source. The American Phytopathological Society, 2011. similarities in species descriptions (9), differences in conditions required to produce diagnostic reproductive structures (3), or the complete absence of diagnostic structures $(8,35)$. As a consequence, many studies of Pythium in forest nurseries have not reported species identity. DNA sequence analysis offers a less ambiguous way to determine species identity, and molecular techniques based on the internal transcribed spacer (ITS) region have been increasingly used to identify isolates of Pythium $(3,8,24,35)$. Levesque and de Cock (24), for example, used ITS sequences to characterize numerous Pythium species and to illustrate phylogenetic relatedness.

Soil dilution plate and plant-based baiting assays have been commonly used to detect Pythium species from soils $(7,12$ $14,17,43)$. However, little is known about how these methods influence the number (richness) and relative abundances of the Pythium species recovered. A limited number of studies have shown an effect of isolation method on Pythium species recovery $(36,37)$. Pettitt et al. (36), for example, found that P. ultimum var. sporangiferum zoospores generally colonized fewer rhododendron leaf disk baits than hemp seed baits. Pittis and Colhoun (37) also reported preferential colonization of plant baits by several Pythium species, but more readily detected several species by directly plating water samples on a semiselective medium. As both types of assay continue to be used to assess Pythium species diversity $(3,17,26,35-37)$, a better understanding of how each influences the detection of Pythium populations and communities is critical.

Information regarding the influence of storage conditions on Pythium populations within soil samples is also relatively scarce $(5,10)$. In some cases, significant time and labor constraints place limits on the number of soil samples that can be processed at one time. Two studies indicate that Pythium populations remain relatively stable during storage. Golden et al. (10) detailed the effect of temperature on populations of several Pythium species in agricultural soils stored for up to 8 weeks. Although isolation frequency tended to decrease initially, by 8 weeks soil populations of Pythium kept at storage temperatures of 10,15 , and $20^{\circ} \mathrm{C}$ were approximately the same as the populations detected prior to storage. Likewise, DeVay et al. (5) found that air-dried or moist soil samples stored at 4 or $23^{\circ} \mathrm{C}$ for up to 5 months did not have Pythium 
populations that were significantly different from those detected at the time of soil collection.

Three forest nurseries in Oregon and Washington were surveyed in 2008 to assess the diversity of Pythium species associated with conifer seedling production. Three isolation methods (one dilution plate and two baiting methods) were used to examine the diversity of Pythium species from each nursery. The objectives of this research were to: (i) identify Pythium species associated with the three forest nurseries; (ii) compare the three isolation methods for assessment of Pythium species richness and abundance; and (iii) determine whether storage of soil samples for 2 weeks significantly affects detection of Pythium species richness and abundance.

\section{Materials and Methods}

Nurseries. One 1.3-ha field plot was established at each of three barefoot forest nurseries in Oregon and Washington in August 2008. Nursery A is located in southwestern Washington on soil classified as Cagey loamy sand with 3\% organic matter. Nurseries $\mathrm{B}$ and $\mathrm{C}$ are located in northwestern Oregon on soil classified as Canderly sandy loam with $4 \%$ organic matter. Each nursery was at least $7.7 \mathrm{~km}$ from the next nearest nursery. All field plots used in the experiment had been in conifer seedling production for at least 35 years. Nurseries A and B were bare fallow for at least 2 months prior to establishment of the field plots, whereas Nursery $\mathrm{C}$ had been planted with a Sudan grass (Sorghum bicolor) cover crop approximately 1 month earlier. All field plots were bare fallow at the time of sampling.

Experimental design. Each field plot was subdivided into 24 subplots, each approximately $12 \times 46 \mathrm{~m}$ in size. Soil samples were collected from each plot by taking $202-\mathrm{cm}$-diameter soil cores to a depth of $25 \mathrm{~cm}$ in a randomized pattern. Soil samples were then bulked within each subplot and mixed thoroughly to generate 24 composite samples from each nursery. Soil samples (at approximately $15 \%$ moisture) were stored in sealed plastic bags at $4^{\circ} \mathrm{C}$ until processed.

Sampling and isolation methods. Pythium species were assayed within 3 days of soil sample collection (storage interval $=0$ weeks) by dilution plating and by baiting with either Rhododendron 'Unique' or Douglas-fir. For dilution plating, $10 \mathrm{~g}$ of each composite soil sample was mixed with $90 \mathrm{ml}$ of $0.2 \%$ water agar and shaken for $45 \mathrm{~min}$ at $150 \mathrm{rpm}$. An aliquot $(0.5 \mathrm{ml})$ of the suspension was then spread with a sterile glass rod on each of 10 petri plates containing $20 \mathrm{ml}$ of PARP agar, a semiselective medium for Pythiaceous species (21). Plates were incubated in the dark at $20^{\circ} \mathrm{C}$, and the number of plates yielding at least one $P y$ thium isolate was counted 2 days later. Baiting was conducted using the double-cup leaf disk baiting method of Linderman and Zeitoun (27). Briefly, $15 \mathrm{ml}$ of each composite soil sample was placed in a 150-ml wax paper cup. A second wax paper cup with the bottom cut out and replaced by a double layer of cheesecloth was positioned firmly on top of the soil sample, and $50 \mathrm{ml}$ of distilled water was added to the second cup. Leaves of rhododendron or needles of Douglas-fir were then used to bait for Pythium species. Leaves and needles were initially surface-disinfested by immersion in $0.06 \% \mathrm{NaOCl}$ for $10 \mathrm{~min}$, then rinsed in running tap water for $10 \mathrm{~min}$. After air drying, 10 5-mm-diameter rhododendron leaf disks or $101-\mathrm{cm}$-long Douglas-fir needle segments (cut with a sterile cork borer or razor blade, respectively) were floated on the water surface in each cup at room temperature. After $48 \mathrm{~h}$, leaf disks and needle segments were removed from the cups with sterile forceps, blotted dry on clean paper towels, and plated on PARP agar medium. Plates were incubated at room temperature for 2 days, and the number of baits yielding at least one Pythium isolate was counted. All composite soil samples were stored for 2 weeks at $4^{\circ} \mathrm{C}$ and then assayed a second time (storage interval $=2$ weeks) using the same three isolation methods to determine the effect of soil sample storage on Pythium species richness and abundance.

One hundred isolates (50 from each storage interval) of Pythium were randomly selected from each of the three isolation methods at each nursery (900 isolates total) and identified to species on the basis of the ITS region. Genomic DNA was extracted using a procedure modified from Martin and Semer (30). Briefly, cultures of each Pythium isolate were grown on $20 \mathrm{ml}$ of $10 \%$ clarified V8 juice agar for 3 days $\left(1 \mathrm{~g} \mathrm{CaCO}_{3} / 100 \mathrm{ml} \mathrm{V} 8\right.$ juice strained through eight layers of cheesecloth and then mixed with $900 \mathrm{ml}$ of distilled water and $17 \mathrm{~g}$ of agar). A small amount of hyphae $\left(<1 \mathrm{~mm}^{3}\right)$ was then removed from each culture with a sterile toothpick, transferred to a $500-\mu \mathrm{l}$ microfuge tube containing $100 \mu \mathrm{l}$ of sterile water, and incubated at $95.9^{\circ} \mathrm{C}$ for $5 \mathrm{~min}$. Ten microliters of the extract was then added to a $40-\mu l$ polymerase chain reaction (PCR) reaction mixture containing $20 \mu \mathrm{l} 2.5 \times 5$ Prime HotMasterMix (5 Prime Inc., Gaithersburg, MD), $18 \mu$ of sterile water, and $1 \mu$ l each of $10 \mathrm{mM}$ universal primers ITS1 and ITS4 (44). Amplification was performed in a Veriti Thermal Cycler (Applied Biosystems Inc., Foster City, $\mathrm{CA}$ ) with the following temperature profile: one cycle of $1 \mathrm{~min}$ at $95^{\circ} \mathrm{C} ; 35$ cycles of $1 \mathrm{~min}$ at $95^{\circ} \mathrm{C}, 1 \mathrm{~min}$ at $55^{\circ} \mathrm{C}$, and $1 \mathrm{~min}$ at $72^{\circ} \mathrm{C}$; and $10 \mathrm{~min}$ at $72^{\circ} \mathrm{C}$. PCR products were separated by electrophoresis on a $0.7 \%$ agarose gel in $1 \times$ TAE buffer. Gels were stained with ethidium bromide and photographed under UV light. PCR products were purified using the GenScript QuickClean 5M PCR Purification Kit (GenScript Corporation, Piscataway, NJ) and then sequenced at Macrogen, Inc. (Seoul, South Korea). ITS sequences were compared to sequences available in GenBank using BLAST to identify each isolate to species. Sequences from ex-type cultures or authentic strains as described by van der Plaats-Niterink (41) and Levesque and de Cock (24), including those reported as new or potentially new species $(22,34)$, were used in analyses when available. Sequences with less than 99\% identity to ex-type cultures and authentic strains could be considered as variants of the most closely matched species, or as putative new species. Therefore, these isolates were assigned an affinis designation (e.g., P. aff. attrantheridium) to indicate relatedness to the closest named species match. The identity of each species was confirmed by evaluating up to 10 isolates for morphological characteristics according to the taxonomic keys of van der Plaats-Niterink (41) and Waterhouse (42), or to the original species descriptions $(22,34)$.

Statistical methods. Estimates of Pythium soil populations, regardless of species identity, were calculated for each nursery by averaging the number of Pythium isolates/g soil (dry weight) of each soil sample. Isolation frequency data were analyzed using the chi-square test of independence (39) to determine if the frequency of isolation was independent of nursery, isolation method, and the amount of time that the soil samples were stored. Variances (the measure of variability around a mean) and Bonferonni's 95\% confidence intervals (39) were calculated from mean isolation frequency data for each nursery, isolation method, and storage interval, and then assessed for homogeneity of variances among treatments with Levene's test (23). In order to assess whether sampling effort (i.e., the number of soil samples taken from each nursery) had detected the majority of Pythium species likely to be present at each nursery, species richness curves and associated error terms were computed with EstimateS Version 8.2.0 (4). Sampling curves that approach a horizontal asymptote are indicative that increased sampling effort is unlikely to result in detection of additional species $(11,45)$. Species diversity was quantified for each nursery and isolation method by calculating species richness (the number of species observed), abundance (frequency of each species), evenness index $\mathrm{E}_{5}(28)$, Shannon's $\left(H^{\prime}\right)$ diversity index (29), and Simpson's $(D)$ dominance index (29). The evenness index $\mathrm{E}_{5}$ is a measure of species abundance that is independent of species richness (28). The Shannon index provides a measure of species diversity in a community and takes into account both species richness and abundance (29). Similarly, Simpson's index provides a measure of species diversity, but is weighted toward the abundance of more common species (29). The jackknife procedure was applied to each of the three indices to improve index estimation (29), and differences in results among nurseries and isolation methods were assessed by one-way and two-way analyses of variance 
(ANOVA) with nursery and isolation method as main factors. All analyses were conducted with Minitab Statistical Software (Release 15.1; Minitab, Inc., State College, PA).

\section{Results}

Isolation frequency. Pythium isolates were recovered from soils at each nursery by each isolation method. Soil populations of Pythium averaged $18.1 \pm 1.1$ (mean \pm standard error) propagules/g dry weight soil (ppg) at nursery $\mathrm{C}$, and $38.7 \pm 1.7$ and $42.5 \pm 2.8$ ppg at nurseries A and B, respectively. Pythium was isolated from $69 \%(2,974)$ of the 4,320 plates or baits used during the entire experiment, and chi-square analyses indicated that both nursery and method influenced isolation frequency $(P<0.001)$. For the dilution plate method (480 plates at each nursery), Pythium was isolated from plates more frequently at nursery A (71\%), less frequently at nursery B $(61 \%)$, and least frequently at nursery C (49\%) ( $P \leq 0.043)$. Conversely, for the rhododendron baiting method (480 baits at each nursery), Pythium was isolated more

Table 1. Variances and 95\% confidence intervals (in parentheses) associated with the isolation frequency of Pythium species from soils sampled at three forest nurseries in Oregon and Washington in 2008 using three isolation methods ${ }^{\mathrm{y}}$

\begin{tabular}{lccc}
\hline & \multicolumn{3}{c}{ Isolation method } \\
\cline { 2 - 4 } Nursery & \multicolumn{1}{c}{ Dilution plate $^{z}$} & Rhododendron & Douglas-fir \\
\hline A & $5.56(3.33-10.65)$ a & $4.08(2.45-7.82) \mathrm{a}$ & $4.14(2.49-7.94) \mathrm{a}$ \\
$\mathrm{B}$ & $12.36(7.41-23.68) \mathrm{b}$ & $9.99(5.99-19.14) \mathrm{b}$ & $10.13(6.07-19.40) \mathrm{b}$ \\
$\mathrm{C}$ & $7.38(4.43-14.14) \mathrm{a}$ & $5.94(3.57-11.39) \mathrm{a}$ & $6.01(3.61-11.52) \mathrm{a}$ \\
\hline
\end{tabular}

y Pythium was isolated from 24 soil samples collected at each nursery by plating a soil suspension on PARP agar medium (Dilution plate) (21), or by baiting soil samples with rhododendron leaf disks (Rhododendron) or Douglas-fir needle segments (Douglas-fir) (27).

${ }^{\mathrm{z}}$ Variances (variability associated with mean isolation frequency) followed by the same letter are not significantly different $(P=0.05) . n=48$ soil samples. frequently from baits at nurseries $\mathrm{A}$ and $\mathrm{C}$, which had similar isolation frequencies of 85 and $88 \%(P=0.652)$, respectively, than at nursery B $(73 \%)(P \leq 0.027)$. Likewise, bait isolation frequencies using the Douglas-fir baiting method at nurseries A (69\%) and C (73\%) were similar $(P=0.591)$, and both were greater than at nursery B $(50 \%)(P<0.001)$. Within each nursery, Pythium was always isolated more frequently from rhododendron leaf baits $(73$ to $88 \%$ ) than either Douglas-fir needle baits (50 to $73 \%$ ) or dilution plates (49 to $71 \%)(P \leq 0.034)$. Chi-square analyses indicated isolation frequency was independent of the amount of time that the soil samples were stored $(P \geq 0.072)$ for all nursery and isolation method combinations except at nursery A for the Douglas-fir baiting method $(P=0.025)$.

The variability associated with Pythium isolation frequency was influenced by nursery, but not by isolation method or the amount of time soil samples were stored. Variances associated with each isolation method were always greater at nursery B than either nursery A or C (Table 1), and Levene's tests confirmed that the variances were heterogeneous $(P \leq 0.034)$. Variances also were greater at nursery $\mathrm{C}$ than at nursery $\mathrm{A}$, but results of statistical analyses were not significant $(P \geq 0.497)$. Within each nursery, variances associated with the dilution plate method were always greater than those from either baiting method. However, results of analyses were not significant $(P \geq 0.087)$. Finally, variances were homogeneous regardless of the amount of time that the soil samples were stored $(P \geq 0.245)$. Therefore, pooled data from both storage intervals are presented.

Pythium species identity. A total of 19 Pythium species were isolated from the three nurseries (Table 2). Isolates identified as $P$. irregulare were subdivided into three clades on the basis of ITS sequence identity: $P$. irregulare sensu stricto according to Garzon et al. (8) and P. irregulare groups III and IV according to Matsumoto et al. (31). Isolates identified as $P$. rostratifingens were only 96\% identical to the ITS type sequence (GenBank Accession No. AY707986), but $99 \%$ identical to the ITS sequence of other isolates identified as $P$. rostratifingens $(32,38)$. Six unidentified

Table 2. Abundance of Pythium species isolated from soils sampled at three forest nurseries in Oregon and Washington in 2008 using three isolation methods ${ }^{x}$

\begin{tabular}{|c|c|c|c|c|c|c|c|c|c|c|c|}
\hline \multirow[b]{3}{*}{ Species $^{y}$} & \multirow[b]{3}{*}{$\%$ ID $^{\mathbf{z}}$} & \multicolumn{9}{|c|}{ Nursery } & \multirow[b]{3}{*}{ Tota } \\
\hline & & \multicolumn{3}{|c|}{ A } & \multicolumn{3}{|c|}{ B } & \multicolumn{3}{|c|}{$\mathbf{C}$} & \\
\hline & & Plate & Rhod. & Doug. & Plate & Rhod. & Doug. & Plate & Rhod. & Doug. & \\
\hline P. aphanidermatum & 99 & 0 & 0 & 0 & 0 & 0 & 0 & 1 & 0 & 0 & 1 \\
\hline P. aff. attrantheridium & $94-97$ & 1 & 0 & 0 & 0 & 1 & 0 & 0 & 0 & 0 & 2 \\
\hline P. dissotocum & $99-100$ & 0 & 2 & 4 & 0 & 0 & 0 & 14 & 70 & 56 & 146 \\
\hline P. irregulare & $99-100$ & 78 & 71 & 45 & 22 & 2 & 5 & 12 & 5 & 0 & 240 \\
\hline$P$. irregulare group III & $99-100$ & 13 & 3 & 1 & 0 & 0 & 0 & 0 & 0 & 0 & 17 \\
\hline P. irregulare group IV & $99-100$ & 2 & 0 & 0 & 10 & 0 & 0 & 0 & 0 & 0 & 12 \\
\hline P. aff. macrosporum & $95-98$ & 0 & 8 & 11 & 3 & 19 & 24 & 5 & 6 & 9 & 85 \\
\hline P. mamillatum & 99 & 1 & 0 & 2 & 0 & 0 & 0 & 3 & 1 & 3 & 10 \\
\hline P. aff. mercuriale & 98 & 0 & 0 & 0 & 0 & 0 & 0 & 0 & 1 & 0 & 1 \\
\hline P. middletonii & 99 & 0 & 0 & 3 & 0 & 0 & 0 & 0 & 0 & 0 & 3 \\
\hline P. aff. oopapillum & $83-85$ & 0 & 0 & 0 & 0 & 0 & 0 & 0 & 0 & 2 & 2 \\
\hline$P$. pachycaule & 99 & 0 & 1 & 0 & 0 & 1 & 0 & 0 & 0 & 0 & 2 \\
\hline P. rostratifingens & $96-99$ & 0 & 0 & 2 & 0 & 1 & 0 & 0 & 0 & 0 & 3 \\
\hline P. aff. rostratum & 95 & 0 & 0 & 0 & 0 & 0 & 0 & 0 & 0 & 2 & 2 \\
\hline P. aff. spiculum & $96-98$ & 5 & 2 & 9 & 1 & 1 & 0 & 16 & 4 & 13 & 51 \\
\hline P. sylvaticum & 99 & 0 & 0 & 0 & 27 & 0 & 0 & 25 & 0 & 0 & 52 \\
\hline P. torulosum & $99-100$ & 0 & 10 & 21 & 0 & 0 & 0 & 4 & 1 & 5 & 41 \\
\hline P. ultimum var. ultimum & $99-100$ & 0 & 1 & 1 & 18 & 2 & 3 & 20 & 12 & 9 & 66 \\
\hline P. 'vipa' & $99-100$ & 0 & 2 & 1 & 19 & 73 & 68 & 0 & 0 & 1 & 164 \\
\hline Total isolates & & 100 & 100 & 100 & 100 & 100 & 100 & 100 & 100 & 100 & 900 \\
\hline Total species & & 6 & 9 & 11 & 7 & 8 & 4 & 9 & 8 & 9 & 19 \\
\hline
\end{tabular}

x Pythium was isolated from 24 soil samples collected at each nursery by plating a soil suspension on PARP agar medium (Plate) (21), or by baiting soil samples with rhododendron leaf disks (Rhod.) or Douglas-fir needle segments (Doug.) (27). One hundred isolates were randomly selected from each of the three methods at each nursery and identified to species on the basis of the DNA sequence of the internal transcribed spacer (ITS) region.

y Pythium isolates labeled with an affinis designation (aff.) had an ITS sequence with less than $99 \%$ maximum sequence identity to the ITS region of ex-type cultures or authentic strains deposited at GenBank (22,24,34,41). Pythium isolates designated as $P$. 'vipa' had an ITS sequence with $99 \%$ maximum sequence identity to the ITS region of isolate 96-224 (DQ528743.1) in GenBank $(15,22)$, which was originally assigned the proposed name $P$. 'vipa'.

z $\%$ ID $=$ Percent identity. Values and ranges in values represent the maximum sequence identity of the ITS region of respective Pythium species isolates compared to the ITS region of ex-type cultures or authentic strains deposited at GenBank $(22,24,34,41)$. 
Pythium species had ITS sequences with < $89 \%$ identity to ITS sequences deposited in GenBank, and were assigned names based on the species with the closest ITS sequence match (e.g., $P$. aff. attrantheridium). The ITS sequences of these isolates were at least 11 nucleotides different from those of ex-type or authentic strains. Preliminary observations of the morphology of the two most commonly encountered species, $P$. aff. macrosporum and $P$. aff. spiculum, were similar to the species descriptions, but additional morphological and genetic studies are in progress to determine the exact taxonomic designation of these isolates. One frequently isolated species (18\% of 900 isolates) had an ITS sequence that was nearly identical (1 nucleotide difference) to that of isolate 96-224 (DQ528743.1) in GenBank, which was assigned the proposed name $P$. 'vipa' $(15,22)$. Morphological characteristics of these isolates were similar to those described by Klemsdal et al. (22). These isolates were, therefore, also designated as $P$. ' $v i p a$ ' in this study (Table 2).

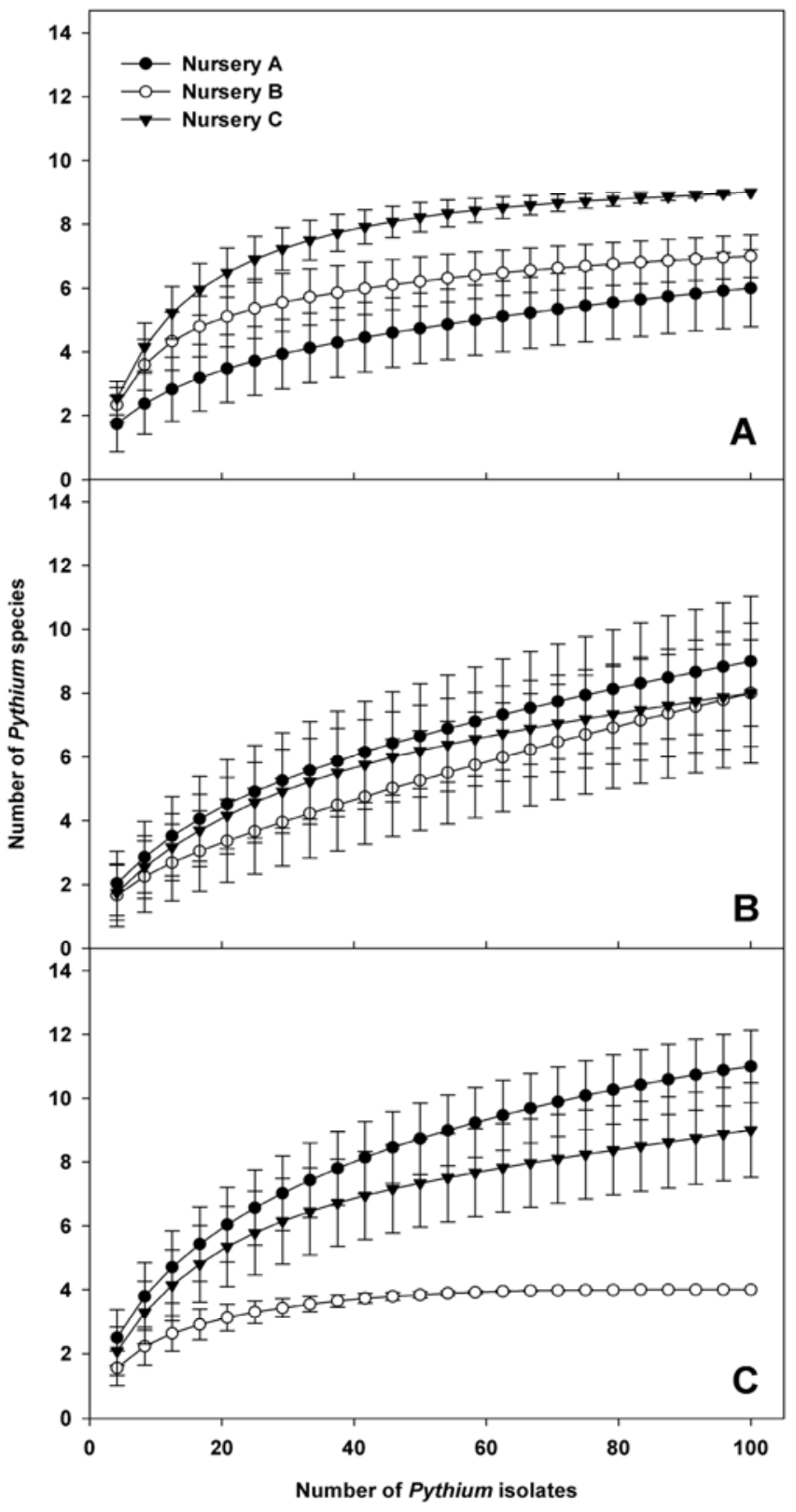

Fig. 1. Pythium species richness curves for soils sampled at forest nurseries $A, B$, and $C$ in Oregon and Washington in 2008 using three isolation methods. Number of Pythium species identified from 100 isolates per nursery and isolation method $\mathbf{A}$, dilution plating, B, rhododendron leaf disk baits, or C, Douglas-fir needle segment baits. Pythium was isolated from 24 soil samples collected at each nursery by plating a soil suspension on PARP agar medium (21), or by baiting soil samples with rhododendron leaf disks or Douglas-fir needle segments (27).
Pythium species richness. Species richness curves approached an asymptote indicating that few additional Pythium species would be detected if sampling effort were increased above 24 soil samples per nursery field plot (Fig. 1). The standard deviation values for each curve from the dilution plate method (Fig. 1A) and for the Douglas-fir bait method at nursery B (Fig. 1C) approached zero, which was also an indication that most of the Pythium species present within each field plot had been detected. However, the slopes of curves from both baiting methods ( 0.03 to 0.05 Pythium species/Pythium isolate) (Fig. 1B and C) were approximately 1.6- to 4.3-fold greater than those from the dilution plate method ( 0.01 to 0.02 Pythium species/Pythium isolate), indicating that increased sampling effort might yield one or two additional Pythium species. The one exception was the richness curve for Douglas-fir baits at nursery B (slope < 0.001), which was the nursery and isolation method combination with the lowest number of detected species. This richness curve rapidly approached an asymptote at four Pythium species, and standard deviation values rapidly approached zero (within 40 to 50 Pythium isolates compared to $>50$ isolates for the other nursery and isolation method combinations).

Species richness was similar for each nursery (nursery $\mathrm{A}=14$ species, nursery $\mathrm{B}=10$ species, and nursery $\mathrm{C}=13$ species), isolation method (13 species detected with each), and for the amount of time that each soil sample was stored $(0$ weeks $=14$ species and 2 weeks $=16$ species) $($ Table 2$)$. Chi-square analyses confirmed that species richness was independent of these variables $(P \geq 0.614)$. However, species composition varied among nurseries and methods. For example, of the 11 species isolated most frequently (those species with $\geq 10 / 900$ total isolates), only six or eight species were the same between any two nurseries. Furthermore, the plating method detected two species, $P$. sylvaticum (52 isolates) and $P$. irregulare group IV (12 isolates), which neither baiting method detected. Although differences were observed in species composition between the two baiting methods and between the two soil storage intervals, the six Pythium species that accounted for these differences were only isolated rarely ( $\leq 3 / 900$ total isolates). For example, $P$. pachycaule, which was only isolated from rhododendron baits and not Douglas-fir baits, was only isolated twice during the entire study.

Pythium species abundance. Species abundance varied markedly among nurseries and isolation methods (Table 2), but not by the amount of time that soil samples were stored. P. irregulare was the most frequently isolated species (240 isolates $=27 \%$ of all 900 isolates), followed by $P$. 'vipa' $(164$ isolates $=18 \%)$ and $P$. dissotocum (146 isolates $=16 \%)$. However, within each nursery, only one of the three most commonly isolated species was predominant. For example, when species counts for each nursery were pooled regardless of isolation method, $P$. irregulare was the most frequently isolated species from nursery A $(194$ isolates $=65 \%), P$. 'vipa' from nursery B $(160$ isolates $=53 \%)$, and $P$. dissotocum from nursery $\mathrm{C}(140$ isolates $=47 \%)$. The relative abundance of other Pythium species also varied by nursery. Several species such as $P$. dissotocum, $P$. 'vipa', and $P$. aff. macrosporum were isolated more frequently by baiting than on dilution plates. Conversely, species such as $P$. sylvaticum, $P$. irregulare group III and IV, and $P$. ultimum var. ultimum were more commonly isolated on dilution plates than from baits. Eight species were rarely encountered $(<10$ isolates total). Therefore, inferences about effects of nursery, isolation method, and soil sample storage were assessed based on pooled frequency data for these species. Chi-square analyses confirmed that species abundance was not independent of nursery $(P<$ $0.001)$ or isolation method $(P \leq 0.001)$, except for species abundances from rhododendron and Douglas-fir baits at nurseries $\mathrm{B}$ and $\mathrm{C}$, which were homogeneous $(P=0.684$ and 0.074 , respectively). Chi-square analyses also indicated that species abundance was not affected by 0 versus 2 weeks of soil sample storage $(P \geq 0.071)$. Therefore, pooled data from the two storage intervals are presented.

Evenness, diversity, and dominance indices. The dilution plate method was the only assay that consistently detected differences 
among nurseries based on the evenness $\left(\mathrm{E}_{5}\right)$, diversity $\left(H^{\prime}\right)$, and dominance $(D)$ indices of Pythium species (Table 3 ). One-way and two-way analyses of variance indicated that evenness was similar at each nursery for each of the baiting methods $(P \geq 0.342)$. However, evenness at nurseries $\mathrm{B}$ and $\mathrm{C}$ was significantly greater than at nursery $\mathrm{A}$ for the dilution plate method $(P=0.002)$. Likewise, diversity was similar at each nursery for the rhododendron baiting method $(P=0.432)$, but significant differences among nurseries were observed for the Douglas-fir baits $(P<0.001)$. For the dilution plate method, diversity was greater at nurseries $\mathrm{B}$ and $\mathrm{C}$ than at nursery A $(P<0.001)$. Dominance was also similar at each nursery for each of the baiting methods $(P \geq 0.133)$, but was least at nurseries $\mathrm{B}$ and $\mathrm{C}$ in comparison to nursery $\mathrm{A}$ for the dilution plate method $(P<0.001)$.

\section{Discussion}

This study adds a number of Pythium species to those already associated with conifer seedling production in the PNW region of the United States. Numerous Pythium species have already been associated with conifers, conifer seedlings, and forest nursery soils (2,13,14,16-19,25,26,33,41,43). Of these, $P$. aphanidermatum, $P$. debaryanum, $P$. irregulare, $P$. mamillatum, and $P$. ultimum were reported as the most common pathogenic species of conifer seedlings. Isolates designated as $P$. debaryanum are probably incorrectly identified, however, as the original description of this species was based on a mixed culture with $P$. intermedium, and the species name has been erroneously applied to other Pythium species including $P$. irregulare, $P$. irregulare group IV, $P$. sylvaticum, and $P$. ultimum $(38,41)$. To the author's knowledge, $P$. dissotocum, $P$. irregulare groups III and IV, and $P$. 'vipa' have not been reported previously from forest nursery soils. Putative new species or species variants such as $P$. aff. macrosporum and $P$. aff. spiculum also were recovered relatively frequently in this study. $P$. aff. attrantheridium, P. aff. mercuriale, P. middletonii, P. aff. oopapillum, $P$. pachycaule, $P$. aff. rostratum, and $P$. rostratifingens were also isolated from forest nursery soils for the first time, but were so rarely detected that they are unlikely to result in disease at the three nurseries surveyed. Studies are underway to determine the pathogenicity and aggressiveness of the Pythium species isolated. Preliminary results indicate that 22 isolates representing 11 of the 19 species (including isolates of $P$. dissotocum, $P$. irregulare, and $P$. 'vipa') can cause Douglas-fir seedling mortality.

The presence of a different predominant Pythium species at each of the three nurseries evaluated in this study illustrates the importance of species identification in assessing soil microbial communities for potential plant pathogens. Hansen et al. (13) noted similar differences in the frequency of Pythium species identified from three forest nurseries located in Oregon and Washington during a fumigation study. They found that $P$. mamillatum was the predominant species isolated at one forest nursery in Oregon $(>70 \%)$, but $P$. irregulare was more frequently isolated at the nursery in Washington and the second nursery in Oregon ( $>60$ and $43 \%$, respectively). Currently, management of weeds and soilborne pathogens in forest nurseries relies on soil fumigation with methyl bromide and chloropicrin, or other chemical fumigants $(13,17)$. Because fumigation acts nonselectively against a broad spectrum of microbes, the identification of genera usually assumed to be pathogenic (i.e., Pythium) to species has often been neglected in forest nurseries. As fumigant use decreases due to increasing state and federal regulations, integrated pest management (IPM) practices and knowledge about the presence and species identity of soilborne pathogens will become critical for effective disease management. Isolates of Pythium species collected during this study will be evaluated for pathogenicity, host range, and fungicide resistance. This information will then be used to develop IPM strategies that target those Pythium species that damage conifer seedlings in forest nurseries.

The ITS sequences of isolates designated as $P$. 'vipa' in the present study were nearly identical to that published by Klemsdal et al. (22). However, in contrast to their observation, the $P$. 'vipa' isolates in this study were more similar to those of $P$. irregulare group IV than to those of $P$. irregulare group III (98\% sequence identity to $\mathrm{AB} 108002$ and $\mathrm{AB} 108004$ versus 94 to $95 \%$ identity to $\mathrm{AB} 108001$ and AB108003, respectively) as described by Matsumoto et al. (31). The ITS sequence of these isolates was consistently different ( $\geq 14$ nucleotide differences) from the ITS sequences of $P$. irregulare group III and IV isolates, the next closest two matches in the P. irregulare species complex. Morphologically, the $P$. 'vipa' isolates matched the description provided by Klemsdal et al. (22), and no sporangia or zoospores were produced from single spore cultures tested with an aqueous salt solution (data not shown). However, the fact that this species was abundantly isolated by both baiting methods suggests that zoospores might be produced under certain conditions.

Dilution plate and baiting assays have the advantage of being relatively easy to implement and assess. Both assays provide cultures of the organisms for use in additional studies. However, as demonstrated in this study, each assay can also have a significant impact on the diversity of Pythium species recovered. Several reasons may account for these differences $(1,36-38)$. For example, baiting methods may initially select for species that are able to quickly form sporangia and release zoospores (1). The short period of assessment following plating of soil and baits then favors Pythium species that grow rapidly (38). Slower growing species, or those unable to form sporangia and zoospores in the baiting assay, are less likely to be detected by these methods. Furthermore, each of the three methods utilized a different carbon source (V8 juice agar versus the two plant baits), which may select for Pythium species that are best able to colonize each substrate. Despite these inherent biases, these isolation methods continue to be popular among researchers for assessing Pythium species diversity $(3,13,19,35)$.

Homothallism and heterothallism have been suggested to affect whether baiting or plating methods are more appropriate for isolation of Phytophthora species $(7,20)$, and the concept may also extend to Pythium species. Ferguson and Jeffers (7) suggested that baiting was a better method for detecting homothallic species of Phytophthora than soil plating because the oospores of these species do not consistently germinate on selective agar media (20). Conversely, heterothallic species that do not routinely produce oospores in soil are detected more easily by plating onto selective media than by baiting. Conflicting evidence for the effect of homothallism and heterothallism on isolation of Pythium species was observed in the present study. Although the homothallic spe-

Table 3. Evenness, diversity, and dominance indices ${ }^{\mathrm{x}}$ of Pythium species isolated from soils sampled at three forest nurseries in Oregon and Washington in 2008 using three isolation methods ${ }^{y}$

\begin{tabular}{|c|c|c|c|c|c|c|c|c|c|}
\hline \multirow[b]{2}{*}{ Nursery } & \multicolumn{3}{|c|}{ Evenness index $\mathbf{E}_{5}$} & \multicolumn{3}{|c|}{ Shannon's diversity index $H^{\prime}$} & \multicolumn{3}{|c|}{ Simpson's dominance index $D$} \\
\hline & Plate $^{\mathrm{z}}$ & Rhod. & Doug. & Plate & Rhod. & Doug. & Plate & Rhod. & Doug. \\
\hline A & $0.5(0.04) \mathrm{a}$ & $0.4(0.05) \mathrm{a}$ & $0.5(0$ & $(0.09) \mathrm{a}$ & $1.2(0.11) \mathrm{a}$ & $1.8(0$ & $0.6(0.04) \mathrm{a}$ & $0.5(0.05) \mathrm{a}$ & $0.3(0.06) \mathrm{a}$ \\
\hline B & $0.9(0.07) b$ & $0.4(0.12) \mathrm{a}$ & $0.6(0$. & $1.8(0$. & $1.0(0.10) \mathrm{a}$ & $0.9(0.0$ & 0.2 & a & $0.5(0.07) \mathrm{a}$ \\
\hline $\mathrm{C}$ & $0.8(0.07) b$ & $0.3(0.14) \mathrm{a}$ & $0.4(0.10) \mathrm{a}$ & $2.0(0.07) \mathrm{b}$ & $1.2(0.18) \mathrm{a}$ & $1.6(0.14) \mathrm{ab}$ & $0.2(0.02) b$ & $0.6(0.16) \mathrm{a}$ & $0.4(0.09) \mathrm{a}$ \\
\hline
\end{tabular}

\footnotetext{
${ }^{x}$ Mean jackknifed values (and standard errors) for each index $(28,29)$.

y Pythium was isolated from 24 soil samples collected at each nursery by plating a soil suspension on PARP agar medium (Plate) (21), or by baiting soil samples with rhododendron leaf disks (Rhod.) or Douglas-fir needle segments (Doug.) (27).

${ }^{\mathrm{z}}$ Index values followed by the same letter are not significantly different $(P=0.05) . n=100$ isolates per mean.
} 
cies $P$. dissotocum was detected more frequently by baiting than by plating, the opposite was observed for $P$. irregulare and $P$. ultimum var. ultimum, two other homothallic species. The heterothallic species $P$. sylvaticum, and the closely related $P$. irregulare groups III and IV $(24,31)$, were rarely detected by baiting in the present study. Schroeder et al. (38) were similarly unable to isolate $P$. sylvaticum by baiting with grass blades. On the other hand, isolates of $P$. aff. macrosporum and $P$. 'vipa', which are closely allied with heterothallic species ( $P$. macrosporum and $P$. sylvaticum, respectively), were more frequently isolated by baiting. $P$. aff. macrosporum isolates obtained in this study only produced oospores in paired cultures, suggesting that these isolates are heterothallic. However, it should be noted that the thallism of $P$. 'vipa' has not yet been established. As a result of these observations, it appears that neither homothallic nor heterothallic Pythium species are preferentially isolated by either plating or baiting methods. It does appear, however, that direct soil plating is preferable for the detection of the heterothallic species $P$. sylvaticum and $P$. irregulare groups III and IV.

Based on results from this study, the dilution plate method had several advantages over the baiting methods in assessing Pythium species from forest nursery soils. First, the dilution plate method allowed for easy quantification of Pythium propagules per gram of soil. Second, dilution plating was the only method that distinguished among the three nurseries based on Pythium isolation frequency. Third, dilution plating consistently enabled detection of all of the most frequently isolated species (i.e., $>10$ isolates of a species were observed). Although species such as $P$. dissotocum, $P$. aff. macrosporum, and $P$. 'vipa' were isolated less frequently by dilution plating than by baiting, dilution plating was the only method that enabled detection of $P$. sylvaticum and $P$. irregulare group IV. The only species that were not consistently isolated by dilution plating were those that were rarely encountered within each nursery $(<10$ isolates per species) such as $P$. middletonii. Once these eight infrequently isolated species were removed from quantitative analyses, the dilution plate method detected more of the common species than either baiting method at nurseries B and C. Finally, dilution plating allowed nurseries $\mathrm{B}$ and $\mathrm{C}$ to be distinguished from nursery A based on evenness and dominance indices. The method also provided two of the three greatest values $\left(H^{\prime}=1.8\right.$ and 2.0) for the Shannon diversity index.

As a result of this study, several Pythium species have been added to the list of species known to be associated with forest nursery soils in the PNW. Once pathogenicity and aggressiveness studies are completed, this knowledge will be valuable for the development of management strategies to target those Pythium species that cause disease in conifer seedlings. In addition, the study illustrates the importance of understanding the selection bias inherent to pathogen detection methods. Each isolation method significantly affected which Pythium species were detected, as well as their respective isolation frequencies. This information allows researchers to select the method that best detects a particular Pythium species. Molecular techniques, such as real-time PCR, may offer a less biased approach for quantification of Pythium species from soils (38). However, knowledge of the Pythium species obtained from this study is critical for the development of species-specific primers utilized by these approaches. Finally, the results confirm that soil sample storage for 2 weeks at $4^{\circ} \mathrm{C}$ does not significantly affect Pythium species richness or abundance compared to soils tested immediately after sampling. This finding allows more flexibility in the allocation of time for soil sample processing and enhances the efficient use of time and labor.

\section{Acknowledgments}

I thank Anne Davis, Bryan Beck, and Duncan Kroese for technical assistance. Financial support was provided by the Pacific Area Wide Pest Management Program for Methyl Bromide Alternatives.

\section{Literature Cited}

1. Arcate, J. M., Karp, M. A., and Nelson, E. B. 2006. Diversity of Peronosporomycete (oomycete) communities associated with the rhizosphere of different plant species. Microb. Ecol. 51:36-50.

2. Børja, I., Sharma, P., Krekling, T., and Lönneborg, A. 1995. Cytopathological response in roots of Picea abies seedlings infected with Pythium dimorphum. Phytopathology 85:495-501.

3. Broders, K. D., Wallhead, M. W., Austin, G. D., Lipps, P. E., Paul, P. A., Mullen, R. W., and Dorrance, A. E. 2009. Association of soil chemical and physical properties with Pythium species diversity, community composition, and disease incidence. Phytopathology 99:957-967.

4. Colwell, R. K. 2006. EstimateS: Statistical estimation of species richness and shared species from samples. Version 8.2.0. User's Guide and Application, published at: http://purl.oclc.org/estimates.

5. DeVay, J. E., Garber, R. H., and Matheron, D. 1982. Role of Pythium species in the seedling disease complex of cotton in California. Plant Dis. 66:151-154.

6. Dumroese, R. K., and James, R. L. 2005. Root diseases in barefoot and container nurseries of the Pacific Northwest: Epidemiology, management, and effects on outplanting performance. New For. 30:185-202.

7. Ferguson, A. J., and Jeffers, S. N. 1999. Detecting multiple species of Phy tophthora in container mixes from ornamental crop nurseries. Plant Dis. 83:1129-1136.

8. Garzon, C. D., Geiser, D. M., and Moorman, G. W. 2005. Amplified fragment length polymorphism analysis and internal transcribed spacer and coxII sequences reveal a species boundary within Pythium irregulare. Phytopathology 95:1489-1498.

9. Garzon, C. D., Yanez, J. M., and Moorman, G. W. 2007. Pythium cryptoirregulare, a new species within the $P$. irregulare complex. Mycologia 99:291-301.

10. Golden, J. K., Powell, W. M., and Hendrix, F. F., Jr. 1972. The influence of storage temperature on recovery of Pythium spp. and Meloidogyne incognita from field soils. Phytopathology 62:819-823.

11. Gotelli, N. J., and Colwell, R. K. 2001. Quantifying biodiversity: Procedures and pitfalls in the measurement and comparison of species richness. Ecol. Lett. 4:379-391.

12. Hansen, E. M., Hamm, P. B., Julis, A. J., and Roth, L. F. 1979. Isolation, incidence and management of Phytophthora in forest tree nurseries in the Pacific Northwest. Plant Dis. Rep. 63:607-611.

13. Hansen, E. M., Myrold, D. D., and Hamm, P. B. 1990. Effects of soil fumigation and cover crops on potential pathogens, microbial activity, nitrogen availability, and seedling quality in conifer nurseries. Phytopathology 80:698-704.

14. Hendrix, F. F., Jr., and Campbell, W. A. 1968. Pythiaceous fungi isolated from southern forest nursery soils and their pathogenicity to pine seedlings. For. Sci. 14:292-297.

15. Hermansen, A., Herrero, M. L., Gauslaa, E., Razzaghian, J., Nærstad, R., and Klemsdal, S. S. 2007. Pythium species associated with cavity spot on carrots in Norway. Ann. Appl. Biol. 150:115-121.

16. Husted, L. D., and Barnes, S. 1990. Dieback of container-grown Douglas-fir seedlings. Forest Research Development Agreement Report 142. Forestry Canada, Victoria, BC.

17. James, R. L. 2000. Effects of a 2-year fallow period on soil populations of Fusarium, Trichoderma, and Pythium species after incorporating corn plant residues. USDA Forest Service Nursery, Coeur D'Alene, Idaho. Forest Health Protection Report 00-17.

18. James, R. L. 2002. Effects of spring applications of dazomet on root diseases and performance of Douglas-fir and western white pine transplants USDA Forest Service Nursery, Coeur d'Alene, Idaho. Forest Health Protection Report 02-9.

19. James, R. L., Knudsen, G. R., and Morra, M. J. 2004. Preplant soil treatment effects on production of Douglas-fir seedlings at the USDA Forest Service Nursery, Coeur D'Alene, Idaho. Forest Health Protection Report 04-12.

20. Jeffers, S. N., and Aldwinckle, H. S. 1987. Enhancing detection of Phytophthora cactorum in naturally infested soil. Phytopathology 77:14751482 .

21. Kannwischer, M. E., and Mitchell, D. J. 1978. The influence of a fungicide on the epidemiology of black shank of tobacco. Phytopathology 68:17601765 .

22. Klemsdal, S. S., Lund, G., Hermansen, A., Herrero, M. L., and Wanner, L. A. 2008. PCR-based identification of Pythium spp. causing cavity spot in carrots and sensitive detection in soil samples. Plant Pathol. 57:877-886.

23. Levene, H. 1960. Robust test in the equality of variance. Pages 278-292 in: Contributions to Probability and Statistics. I. Olkin, ed. Stanford University Press, Palo Alto, CA.

24. Levesque, C. A., and de Cock, A. W. A. M. 2004. Molecular phylogeny and taxonomy of the genus Pythium. Mycol. Res. 108:1363-1383.

25. Lilja, A. 1994. The occurrence and pathogenicity of uni- and binucleate Rhizoctonia and Pythiaceae fungi among conifer seedlings in Finnish forest nurseries. Eur. J. For. Pathol. 24:181-192.

26. Linde, C., Kemp, G. H. J., and Wingfield, M. J. 1994. Pythium irregulare associated with Pinus seedling death on previously cultivated lands. Plant Dis. 78:1002-1005.

27. Linderman, R. G., and Zeitoun, F. 1977. Phytophthora cinnamomi causing root rot and wilt of nursery-grown native western azalea and salal. Plant Dis. Rep. 61:1045-1048. 
28. Ludwig, J. A., and Reynolds, J. F. 1988. Statistical Ecology: A primer on Methods and Computing. John Wiley \& Sons, New York.

29. Magurran, A. E. 1988. Ecological Diversity and Its Measurement. Princeton University Press, Princeton, NJ.

30. Martin, F. N., and Semer, C. R., IV. 1997. Selection of drug-tolerant strains of Pythium sylvaticum using sublethal enrichment. Phytopathology 87:685692.

31. Matsumoto, C., Kageyama, K., Suga, H., and Hyakumachi, M. 2000. Intraspecific DNA polymorphisms of Pythium irregulare. Mycol. Res. 104:13331341.

32. McLeod, A., Botha, W. J., Meitz, J. C., Spies, C. F. J., Tewoldemedhin, Y. T., and Mostert, L. 2009. Morphological and phylogenetic analyses of $P y$ thium species in South Africa. Mycol. Res. 113:933-951.

33. Middleton, J. T. 1943. The taxonomy, host range and geographical distribution of the genus Pythium. Mem. Torrey Bot. Club 20:1-171.

34. Paul, B., Bala, K., Lassaad, B., Calmin, G., Sanchez-Hernandez, E., and Lefort, F. 2006. A new species of Pythium with ornamented oogonia: Morphology, taxonomy, internal transcribed spacer region of its ribosomal RNA, and its comparison with related species. FEMS Microbiol. Lett. 254:317-323

35. Paulitz, T. C., and Adams, K. 2003. Composition and distribution of Pythium communities in wheat fields in eastern Washington state. Phytopathology 93:867-873.

36. Pettitt, T. R., Wakeham, A. J., Wainwright, M. F., and White, J. G. 2002. Comparison of serological, culture, and bait methods for detection of $P y$ thium and Phytophthora zoospores in water. Plant Pathol. 51:720-727.
37. Pittis, J. E., and Colhoun, J. 1984. Isolation and identification of pythiaceous fungi from irrigation water and their pathogenicity to Antirrhinum, tomato and Chamaecyparis lawsoniana. Phytopathol. Z. 110:301 318.

38. Schroeder, K. L., Okubara, P. A., Tambong, J. T., Levesque, C. A., and Paulitz, T. C. 2006. Identification and quantification of pathogenic Pythium spp. from soils in eastern Washington using real-time polymerase chain reaction. Phytopathology 96:637-647.

39. Sokal, R. R., and Rohlf, F. J. 1995. Biometry. W. H. Freeman, New York.

40. Sutherland, J., and Dennis, J. 1992. Pythium water mould in British Columbia forest nurseries. Seed Seedling Ext. Topics 5:9-10.

41. van der Plaats-Niterink, A. J. 1981. Monograph of the Genus Pythium. Stud. Mycol. 21:1-242.

42. Waterhouse, G. M. 1968. Key to Pythium Pringsheim. Mycol. Pap. 109:1-

43. Weber, R. W. S., Sulzer, F. L., and Haarhaus, M. 2004. Pythium undulatum, cause of root rot of Abies procera Christmas trees and Pseudotsuga menziesii in northern Germany. Mycol. Prog. 3:179-188.

44. White, T. J., Bruns, T., Lee, S., and Taylor, J. 1990. Amplification and direct sequencing of fungal ribosomal RNA genes for phylogenetics. In: PCR Protocols: A Guide to Methods and Applications. M. A. Innis, D. H. Gelfand, and J. J. Snisky, eds. Academic Press, Inc., New York.

45. Williams, V. L., Witkowski, E. T. F., and Balkwill, K. 2007. The use of incidence-based species richness estimators, species accumulation curves and similarity measures to appraise ethnobotanical inventories from South Africa. Biodivers. Conserv. 16:2495-2513. 